\section{THE METHOD OF \\ DEFINING THE FRAME \\ OF THE STREET}

\section{AZ UTCA TERÜLETI MEGHATÁROZÁSÁNAK MÓDSZERE}

SZERZŐ/BY: ANNA PECZE,
PETER ISTVAN BALOGH

ABSTRACT

The paper is about defining the boundary of the street. Most of the literature define the facades of the buildings as the boundary of the street dividing the space into internal and external, separating the private from the public area. Furthermore, reduce the street only to the public areas. The paper analyzes if the street is strictly limited to the public areas or it includes more. It is ascertained that the area of the street extends beyond the physical frame. To determine the exact area of the street the different ways of experiencing the environment were analyzed. It is said that including the human factor into the street analyzes is necessary. Therefore, different perception methods are used. These are dynamic, static, objective or subjective method. Thereby it is established that the frame of the treet the physical boundary and contains the areas that observer perceives. To sum up the paper is giving a base Tor establishing a ner methodology of rban-aring a hat the subjective pereption of the street gives even more bout the settlement as with trang resear human fan ber ming posite to in the subjective experesco posible to nvolve Defining a rew in Defer streets, but at the same time finding research become effective, is the fulcrum Define a new method of urban-

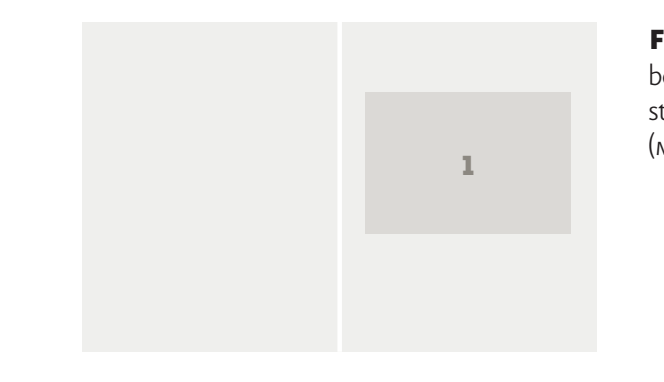

AUTнor)

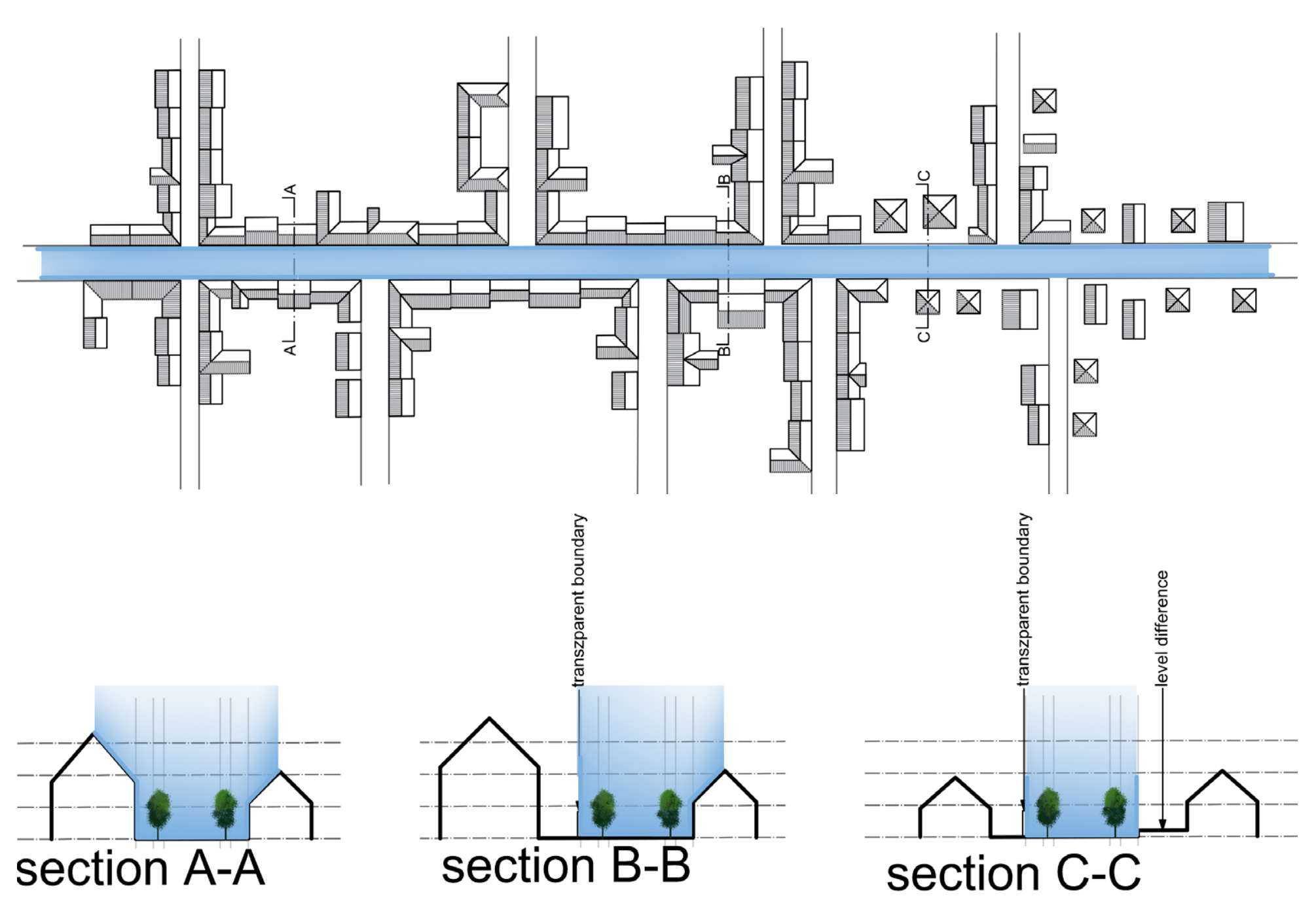

of this paper, which will be elaborated in the Ph.D. in progress of the author.

Keywords: main street, perception subjective experience of the surrounding. senses

"The streets, like squares, need walls to differentiate the original, infinite space into internal and external space. To sum up, accoring to most literature, the street is framed by element that define the outer and inner space, separating the private from the public space. These are mainly the walls that surround the street, namely the facades of buildings.

1. THE AREA OF THE STREET

Defining the area of the street is a complex process. The literature defines the street based on different theores. Accring to Tás Meggyesi, the street is a wider space, bounded Jyn Gehl in his book Cities for People. wites that the streetis bounded by wites that the street is bounded by borders, separating the outdoor and That kind of definition of the area of the street is not completely complete. Gordon Cullen in his book The Concise Townscape defines different physical boundaries that differentiate the space which are linking and joining the different characters of space. Cullen defines these boundailes as hazards, despite of differentiate the spaces of different character they maintain the
1 Meggyesi Tamás (2006): Városépitészet, Egyetemi jegyzet, Budapest Budapes $\mathbf{3}$ Tótht Zoltán (1999) A települések vilaga,
Ponte Press Kiadó, Pécs, 116 


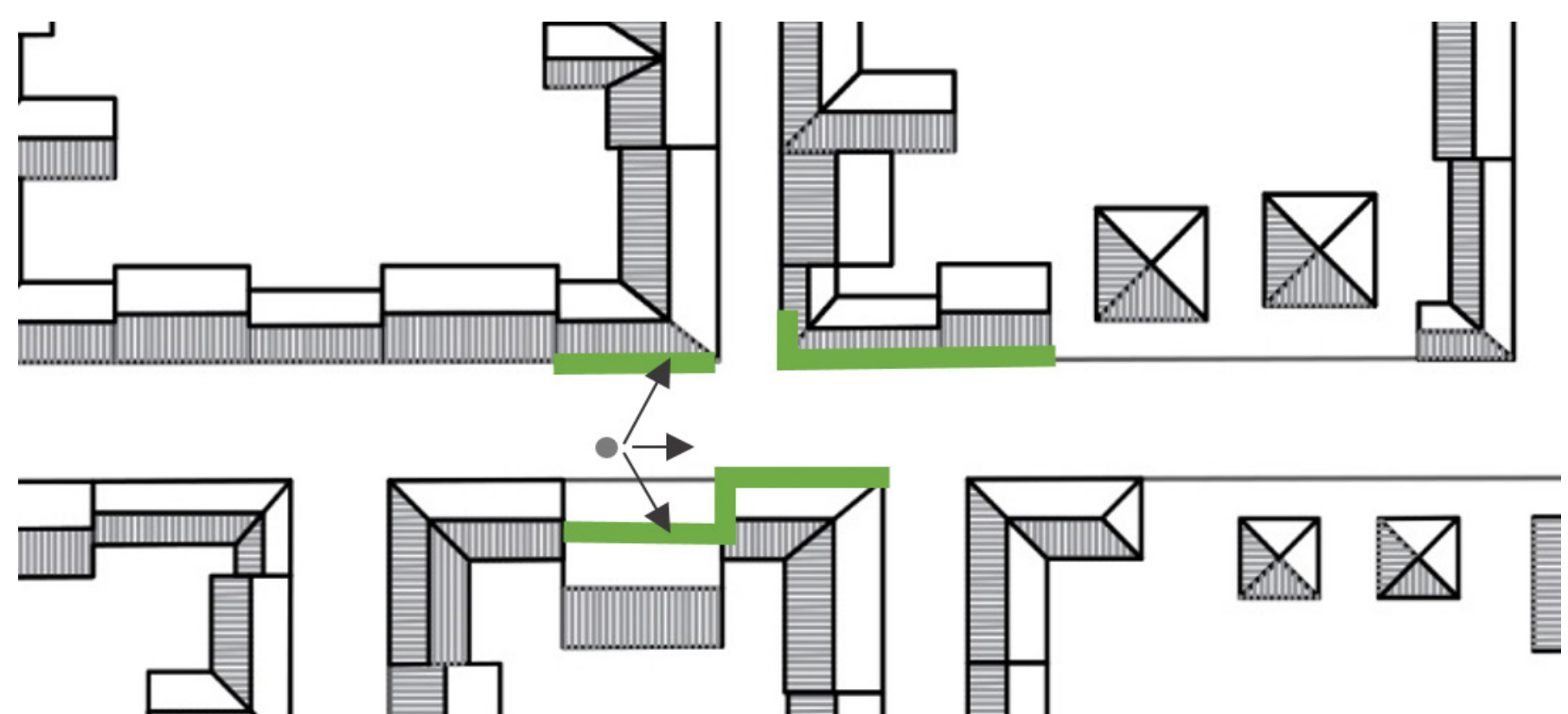

visual connection. Cullen lists the following elements: grid, vegetation, hidden obstacle and level difference A question appears if the street is strictly limited to the public areas or it includes the areas that have only 政 fin the answre the research analyzes thire human factor into the stret a

2. THE DIFFERENT WAYS OF

EXPERIENCING THE ENVIRONMENT

Edward Hall in his book, Hidden Dimensions studies the relationship between the person and the environment on a physiological, social and cultural level, as the relationship between the person ment is largely determined by their culture and education. $\mathrm{He}$ writes that "... people of different cultures seak not only different languages but ... perceive the world in a different way." re taken by sensory organs: skin, eyes, nose, mouth, and ear. Juhani Pallasmaa ine the imp "The sizes the importance and domination of understanding the environment by touching. He says that vision is a kind of scanning or touching the surrounding with our eyes. The relationship between people and the environment was also between the people and their environment come from the nature of the studied by Pallasmaa. He came to realiz that one of the strongest connection peripheral vision. For example, "a forest or a detailed building provides a sufficient stimulus for peripheral vision and thus places us in the center of the space. From Pallasmaa's point of view vision is the most complex and most sensitive information provider from the human senses.

Pallasmaa defined the relationshi between the observer and his environment as: "I come into contact with the city through my body: my steps measure the length of the arcade and the widt of the square; $\ldots$ the mass of my body crashes in the severity of the cathedra gate and my hand seizes the large handle gre lies behind it." (Pallasm encies in urba that it is analyzing outside, focusing ny on the sighted ones. That is why it pareal to the subjective part of it. It does not analyze the spirit of space, how people live and how they To sum up, to undestand To sum up, to understand the envimetions but a reat just ga hening informations but a real experience of the surrounding, by skin, eyes, nose, mout and ear. Thereby a complex picture of our environment can be recelved. Since vision is the most complex and most sensitive information provider, it does not surprise dominating the oth senses. But vision cannot substitute, for example, the information that $c$ be obtained by touch or smell. With the information got only using the eyes the personal contact and attachment to the environment is going to be lost. Thereby instead of experiencing our surroundings and becoming part degrading ourselves as a mere viewe

3. TYPES OF PERCEPTION

The aim of the research is to include the human factor into the analyzes. Since each person senses the surroundings in a unique way. It is necessary to involve subjective point of view, which the research calls the subjective aspect. The way we perceive our environment is always subjective, always personal. According to professor Meggyesi, our environ ment exists in three ways: "Firstly it exist as an independent reality. as objective scientific research and description secondly it exists during the course of the journey, in turing the experiences, and finally for the third time in our mend fin s, for the image tha can be roca a since the environled at any tine" Since the environment exists in three diferent vews, three ways of analyzes exists, too. It is determined that the objective reality of the environment cannot be completely defined by one observer, on the other hand it excludes the human factor The reach is not analyzing it.

The research is focusing on the other two views of perceiving the environmen
6 Juhani Pallasmaa (2018): A bór szeme Dpleszet es erzekek, Typorex, Buda7 Meggyesi Tamás (2011): Promenadovanyelemzés elméletébez Budapest; 5 
that are including the human factor. In other word, the research analyzes the so-called soft aspect of the environmental studies, that are based on the fact how the person feels the environment.

The soft aspect has two types.

The static and the dynamic aspect

of experiencing the environment.

3.1. THE STATIC ASPECT OF

EXPERIENCING THE ENVIRONMENT

(PERCEPTION)

By perception taking up stimuli through the receptors in our senses and turnin them into a stimulus, namely into an electrical impulse is meant. "The proces of perception is the mechanism by which the sensory organs transform environ-

mental information into the experience of objects, events, sounds, tastes, and more There are two main types of

perception: constructive perception an direct perception. According to direct perception, the subect obtans information from the sunsounding world in a way that is optinal, without tise for complex cognitive processes. According to the constructive perception theory, "perception is not objective because the perceptual person builds up the perception based on the perceived stimuli ... add their own experiences and expectations".10 Dung the perception process, the skin, eyes, nose, mouth, ears. In Juhani
Pallasmaa's book, The Eyes of the Skin, thetactile perception as we exp rience our environment is emphasized. Pallasmaa states that "all our senses, including the vision, are an extension of the tactile sense; our senses are the branches of the skin tissue, and any sensory experience is a form of contact, that is to say, touch. This sense is the starting point from which others have differentiated." One of the greatest results of the method described by the research is that it does not look at the settlement as an outsider, it focuses not only on what has been seen but also on the internal relationsips that make the settlement unique.

\section{Merleau-Ponty's philosophy puts man} the center of the world He claims that experience is unified through the body. "To some extent, every ploce con be remembered partly because it is unique reme and evores nough assciation to be preserved in our associntion to be presert to our personalwor norder the a real inage of the entris required The sentos af the senses is required. The senses are not only used to convey information, but also to activate the imagination and thinking. However, the image of our environment changes in our heads based on the person's individuality. This kind of experience of the environment changes by time in our head. Exactly the time is that makes the subjective aspect of perception really important.
8 Roth, Ilona, Frisby, John (1986): Perception and Representation: A Cognito object perception), Open University
Press, Michigan IN Olah and Bugan: Feje $_{-}$ zetek a pszichológia alapterületeiból, ELTE Eöttoös Kiadó, Budapest, 20o6; 38 gia alapterüuleteibob́l, ELTEE Eötuös Kiadó Budapest, 2006

10 Oláh and Bugán: Fejezzetek a pszi-

11 Juhani Pallasmaa (2018): A bör sze-

mei: Épitészet és érzékek, Typorex, Buda

Memory Architecture, Yale University Press; 107

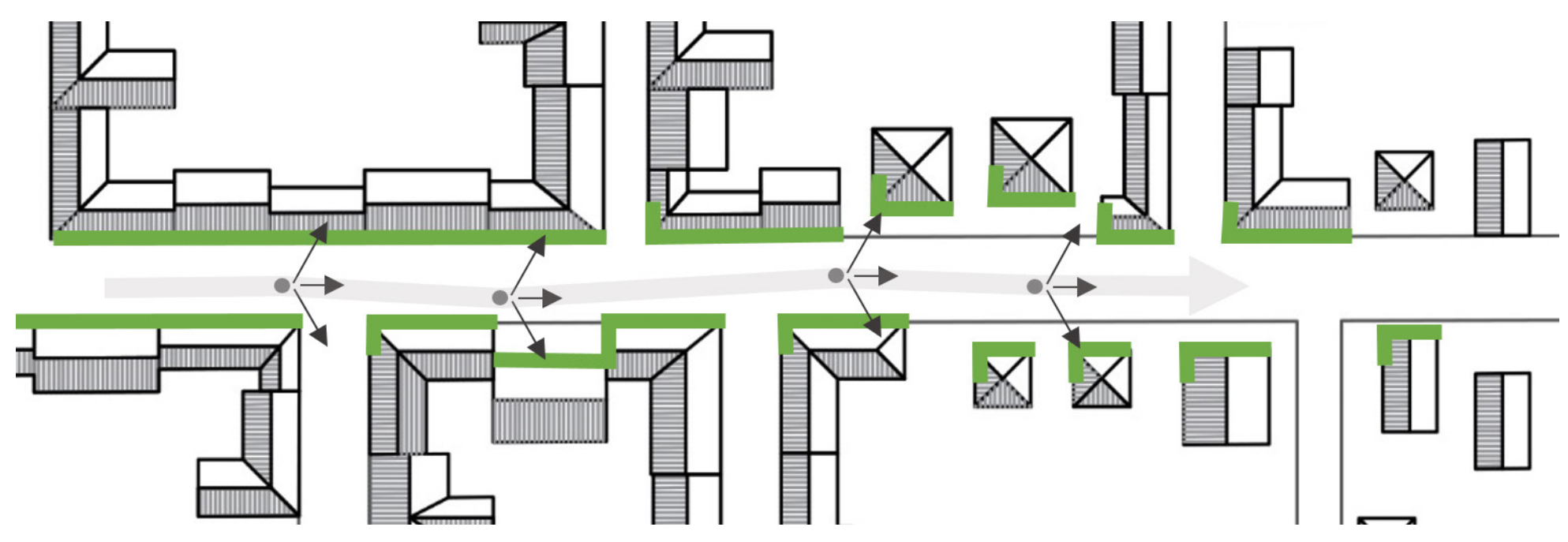

It is always formed by person added extra informations (emotions) or not. To sum up it can be said that the individual's personality and social position have fundental social position have fut impact The view of the enviros

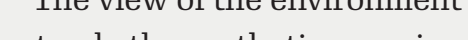
but the image of our idenience but the inage of our identity and relations whe was the place Is whe call the genus loci. the genius loi, dhe dif then

3.2. THE DYNAMIC ASPECT OF EXPERIENCING THE ENVIRONMENT (PROMENODOLOGY)

Promenadology is the rediscovery and interpretation of the urban image by moving. The "precursor" of the method is serial vision which concept was made by Gordon Cullen in 1961. Ser vision formes connection between dynamic and static perception as it consists static views of a moving person along a given path. Cullen said hat should "apprehend urban environments through kinesthetic experience" Dynamic experience of the surrounding requires the concept of distance to be experienced. There is nothing better than walking. After all, 'our body and movement are in constant "our body and the or distance is not statc.". The pare ant is dyna is not static. "... The perception hat is, what can be done in a givent shat is, what can be done in a given static viewing ${ }^{15} \mathrm{~T}$. static viewing. Lu Bius Burckhard, urban sociologist, is considered the founder of the new "science". Since then, several conferences have been held on been launc and In Hung courses have as sightsened. In Hungary it is familiar as sightseeing or walking tours. Rediscovering the walk is the key because the speed has blocked us from experiencing space and landscape. This
13 Cullen, Gordon (1961): The Concise Tow oxscape, (Serbian Edition: 2007), 118 14 Jahani Pallasmaa (2018): A bör szepest; 56
15 Hall, Edward T. (1966): Anchor Books 15 Hall, Edward T. (1966):
Doubleday, New York; 162 Doubleday,, New Yorkh,irdt, Lucius (20o6): Warum
ist Landschaft schön?, Martin Schmitz Verag, Berlin 


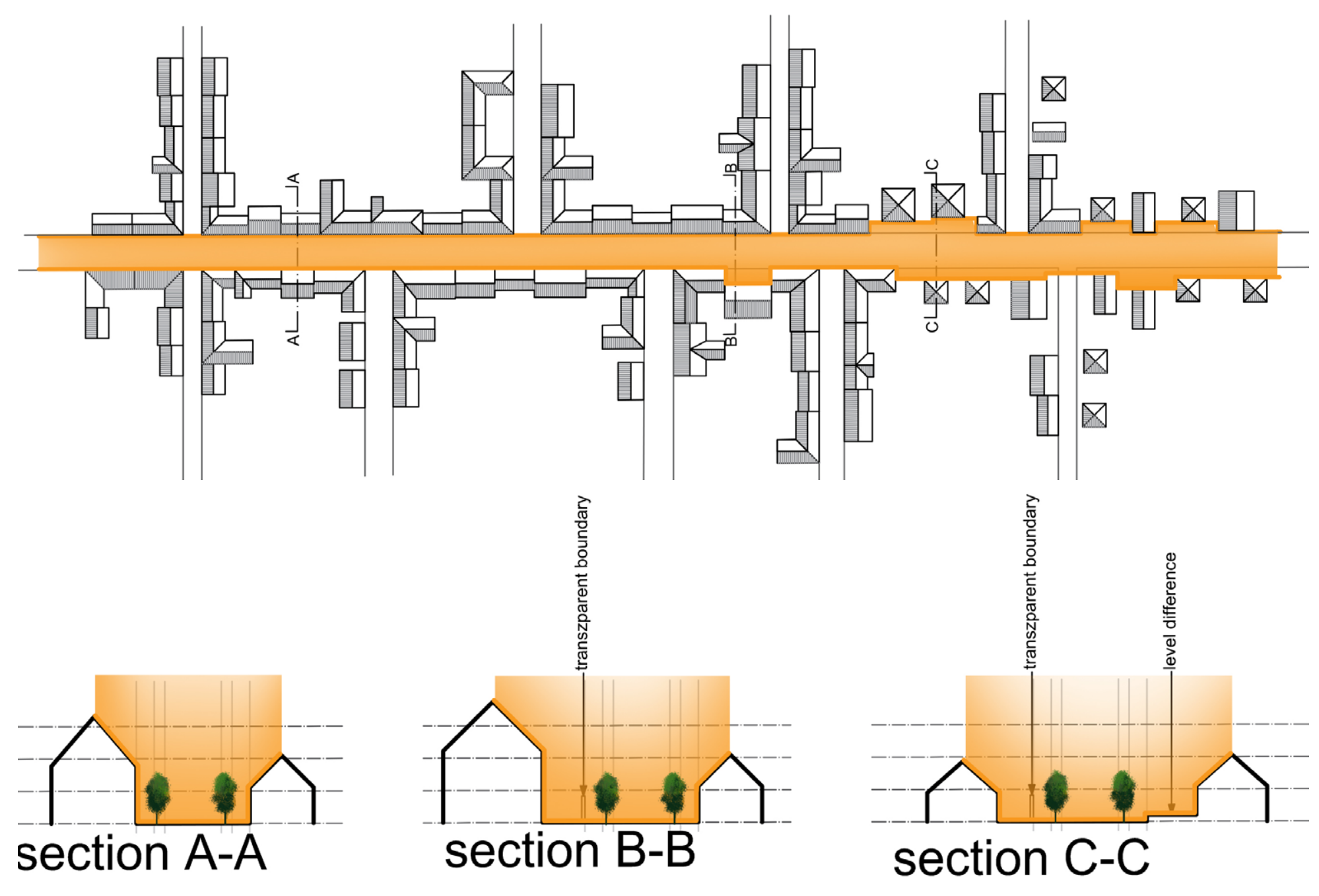

is what promenadology deals with, it can also be called the "science of walking". "For now, promenadology is not a science, but an approach."17" Its aim is the focused and conscious perception of the environment, and to transforming mere vision into perception. ${ }^{18}$ The promenadological approach has only qualitative expectations, the goal is to analyze the whole view and in the light of this, identify the identity of the place. The biggest disadvantage of a static street view is that it is presented from one perspective. Even if multiple images are taken from different perspectives, they remain only mosaic pieces. The complex image of the surrounding cannot be got. According to Lucius Burchkardt, only walking gives direct sense of the environment. Promenadology can be a spatial experience not only for the sighted but also for the blind - although they use a completely different sense to understand their environment. For them pace is perceived through the sensation of touch, sound and its reflection, sense of heat, and fragrance. This creates a ynamic picture of the environment. Walking can be seen as the source of the spatial experience. The usual static street views highlighting just a few moments, but the person is moving constantly, stop only stations that must be surpassed sooner or later. For this reason, it is essential to involv movement in settlement research. During the walk people get in direct contact with the environment. If you are in a settlement for the first time,

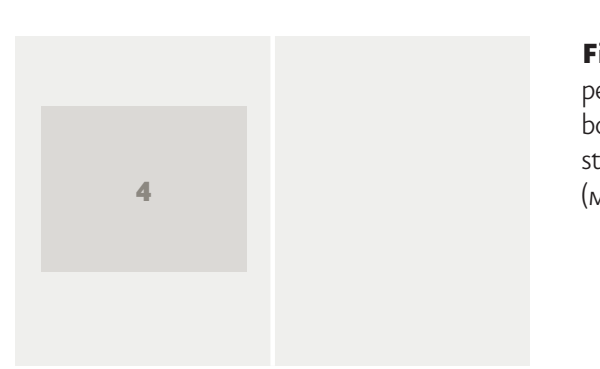

Fig. 4: The
perceptional

indary of the

(MADE BY AUTHO

perhaps your first impressions are the most important: then all our senses are active, and our impressions leave a lasting imprint in our memory. To sum up, one of the key points in the experience of space is the relationship between space and time. To understand the essence of a dynamic spatial experience, we need to clarify the relationship between time and space. In order to experience the time we have to move around in space. According to Szentkirályi, the length of the route is not calculated in meters, but in time" ". we perceive a space as the sum of the potioeive distance between objects is required

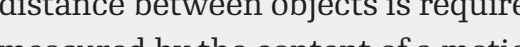
overview or the amount of that can oxperien words, coln other the chan of the environ ind the change the ent time, that is, the sibjective realyation or space. as if we we experiencing

the interference of time and space. In contrast the the exper a static view during the movement thing changes: the viewer who is walking and the environment through which they pass, while they interact with each other so that the two can no longer be separated. It is nothing more than a lively, moving collage or a piece of music where themes like "acoustic event spaces" unfold over time. But we could liken it to narrat it is no coincidence that we know many literary descriptions of a street.
4. THE METHOD OF USING THE DIFFERENT ASPECTS OF PERCEPTION IN THE DEFINING THE AREA OF THE STREET

The most common way of defining the area of the street is based on dividing it on outer and inner, public and private areas, that in most of the cases means the physical boundary of the street that is created by the facades of the buildings.

As it can be seen in both static and dynamic aspects of experiencing more from the public spaces of the street can be perceived. According to Giambattista Nolli it can be said that the street as a public area does not stop at the physiclly enclosed building line As it is visible on the map of $\mathrm{B}$ me in 1748 the inner blocks and the sini public spaces, are inded part of it.

The "urban solid-empty" morphology follows similar approach. The "urban solid" category includes the constructions, that are the borde"unning buildings. However, the the innor the inner blocks, the network of streets and squares, parks, gard and other linear elements.

The urban open space is a free from above external space explored and shaped for human use. In other word the urban open spaces are parts of an uninhabted urban space (urban empty") that have been explored for human use by landscape architecture. ${ }^{22}$
19 Szentkirályi Zoltán (1980): Az épitéAlap Kiadónóllalatotó, Bépzomüvésze 2o Lukovich Tamás (2001): A posztmodern kor városépitészetének kihívásai, Pallas Kiadó, Budapest

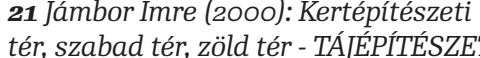
22 Balogh R. I. (2004): A szabadterek szerepvaltozasa a nagy europai varosmeg- 
To sum up, it is obvious that the area of the street extends beyond the physical frame. To determine the exact area of the street getting a complete image of it the experiencing the environment. Thereby included the observer into the process. Owing to the new method of defining the frame of the main street it becomes possible to analyze them including the individual factor, how the people feel and understand the surrounding. The result of the new method is visible on the figure below.

5. CONCLUSION

To sum up, the subject of the paper is about defining the area of the street. According to the most of the literature, the street is framed by elements that define the outer and inner space, separating the private from the public area. These are mainly the walls that surround the street, namely the facades of buildings. In this case the street is strictly limited to the public area. However, the observer senses more of the street. The research was made to find the method of defining the boun
of the street including the subjecof the street including the subjec-
tive aspect, the human factor in it.

tive aspect, the human factor in it.
According to professor Meggyesi, According to professor Meggyesi, our environment exists in three ways: as an independent reality, and as a subjective image perceived by moving and in our memories. ${ }^{23}$ The research is focusing on the two subjective methods of perceiving the environment that are including the human factor. Therefore the different ways of experiencing the environment were analyzed. These are the dynamic and static aspect. According to both the area of the street contains all the areas that have visual connections with the observer. To sum up, the base of defining the frame of the street is given by the different methods of experiencin the environment. It is based on the pace that the observer sees be street or walking along the street. The paper is giving a base for establishing a new methodology of estabrechitectur reserch saying that trome of the street defined by subjective perception contains much mont ro (etre stret can tincludes the of the factor, making possible to involve subjective experience and the differ subjective experience and the different Defining a new method of urban-archDetura a lyze of the man the sane the find the sane time find which will allow that research become effective, is the fulcrum of this paper, which will be elaborated in the Ph.D. in progress of the author. Owing to the new method of defining the frame of the ma street it becomes possible to analyze them including the individual, subjective factor, how the people feel and understand their surroundings.
23 Meggyesi Tamás (2011): Promenadologia: Fejezetetek a séta és a lineáris lát

LITERATUR

GEHL, lan (2010): Élhetöo városok, TERC, Budapest

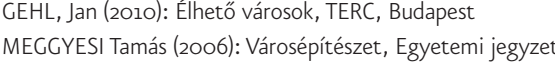
sudapes EECYYESI Tamás (2011): Promenadologia: Fejezetetek aśtá śs

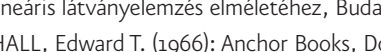
Juhani Pallasmaa (2018): A A bör szemei: Éritészet és érzékeke, Typorex, Buapest Architectural Press, Oxford (Serbia

Edition: 2007) BURCKHARDT, Lucius (2006): Warum ist Landschaft schön? Martin Schmiz Verag, Berlin
HAMVAS Bella (1988): Az öt get

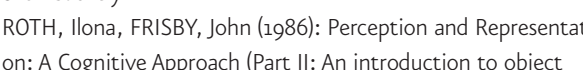

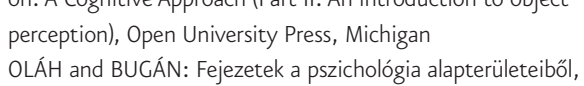
政 kihiváasai, Pallas Kiadó, Budapest JAMBOR Imre (2000): Kertépítészeti tér, szabad tér, zöld tér

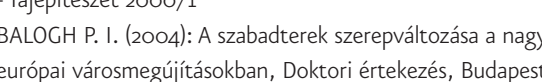

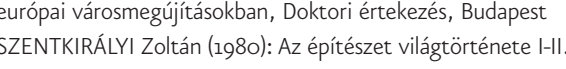

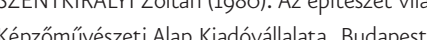

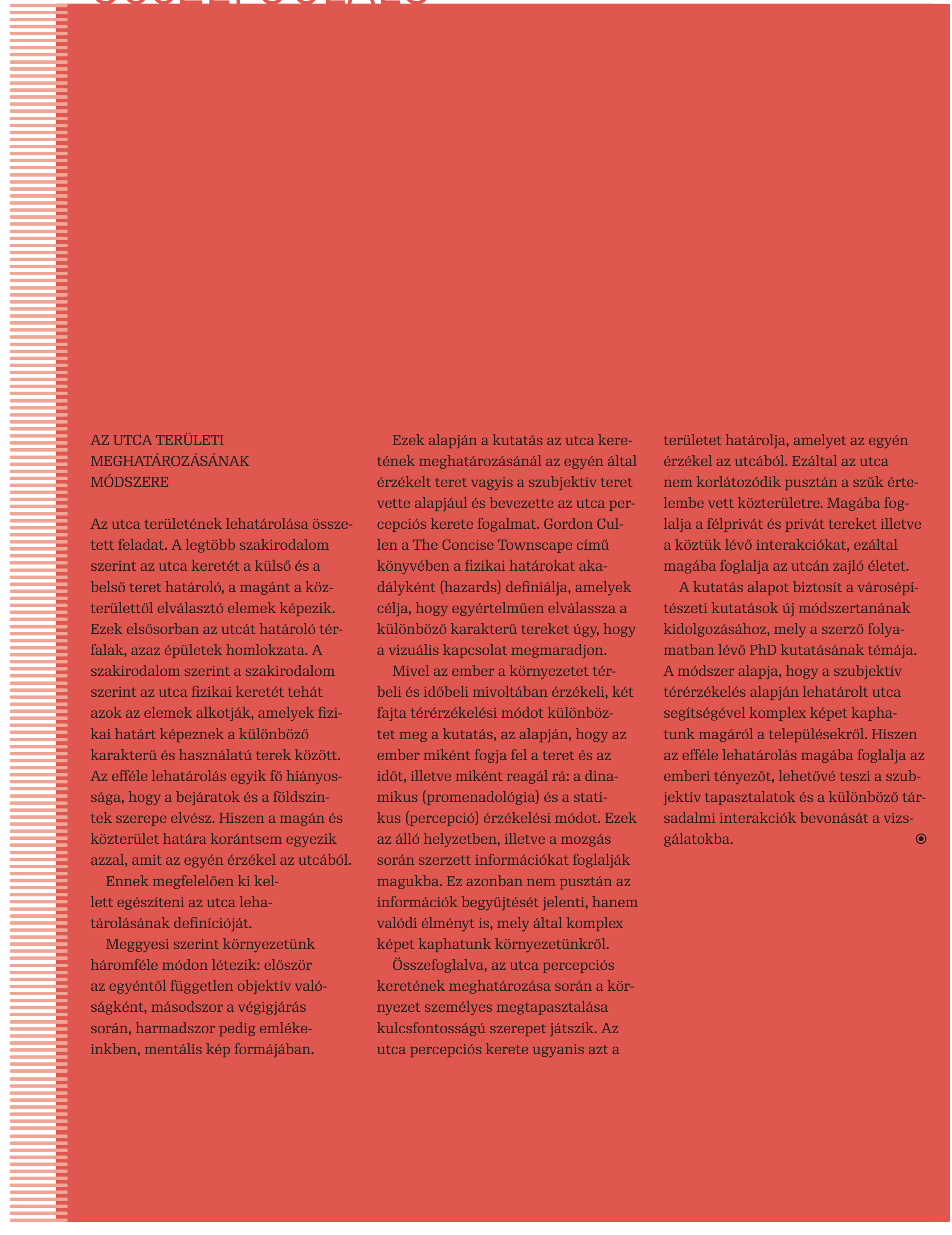

